Journal of Social Sciences 5(1): 33-42, 2009

ISSN 1549-3652

(C) 2009 Science Publications

\title{
Causal Relationships between Financial Development, Trade Openness and Economic Growth: The Case of Turkey
}

\author{
Fatih Yucel \\ Department of Economics, Nigde University, FEAS, 51243 Nigde, Turkey
}

\begin{abstract}
Problem statement: The main objective of this study was to examine the causality relations between financial development, trade openness and economic growth (GDP) for the Turkish economy. Approach: In time series context, recently developed econometric techniques were used: namely the Augmented Dickey-Fuller (ADF) for unit root, Johansen and Juselius (JJ) for cointegration and Granger causality test for causal relationships. Results: The findings of the study showed that while trade openness has a positive effect, financial development has a negative effect on growth. Conclusion: Moreover, the Granger causality test results revealed the presence of bicausal relationship between financial development, trade openness and growth indicating that economic policies aimed at financial development and trade openness have a statistically significant impact on economic growth.
\end{abstract}

Key words: Financial development, trade openness, economic growth, a granger causality test, cointegration test

\section{INTRODUCTION}

Financial development and trade openness policies reduce inefficiency in the production process and positively influence economic growth. This argument is strengthened by the fact that growth rates in countries with trade openness and financial policies outperform those with restrictive financial and trade policies $^{[8,15,18,35]}$.

The existence of a correlation between financial development and economic growth has been documented in a number of empirical studies starting with Cameron ${ }^{[5]}$, Goldsmith ${ }^{[16]}$ and McKinnon ${ }^{[42]}$. Later, many studies were elaborated to verify the relationship between financial development and growth. Demetriades and Luintel ${ }^{[11]}$, Fry ${ }^{[15]}$ and King and Levine $^{[32]}$ are examples of econometrics studies that found a positive relationship between financial development and growth. However, Singh ${ }^{[55]}$ has argued that financial development increases the macroeconomic instability, thereby having a negative effect on economic growth.

There are a priori four possibilities concerning the causal relationship between financial development and economic growth ${ }^{[17]}$ : Financial development and economic growth are not causally related. Neither of the two has considerable effects on the other and the observable (and empirically firmly established) correlation between them are merely the results of a historical peculiarity: economies grew and so did their financial sectors, but the two follow their own logic.
Financial development follows economic development. Economic growth causes financial institutions to change and develop and financial as well as credit markets to grow. Financial development is thus demand-driven. In this view, the lack of financial development is simply a manifestation of the lack of demand for financial system. The demand for kinds of financial services rises thus will be met by financial sector, as the real sectors of the economy grow. Therefore financial development follows economic growth. Financial development is a determinant of economic growth. The line of causation runs from financial development to real development, where financial development, of course, are only one among the many growth-inducing factors, some of them necessary and some (or some combination) of them sufficient. In this point, services provided by the financial system are base for economic growth. As the financial system develops then quantity and quality of investment, thus, will be one of special determinant of economic growth. Financial development may at least occasionally and in the short run-turn out to be an impediment to economic growth. As in hypothesis third, the line of causation runs from financial development to real development, but the focus lies on potentially destabilizing effects of financial overtrading and crises rather than on the smooth functioning of the financial system. This view conceives the financial system as inherently unstable.

Financial development increase economic growth by raising ${ }^{[54]}$ : (i) The ratio of saving to gross domestic 


\section{J. Social Sci., 5(1): 33-42, 2009}

product; (ii) The proportion of saving channeled to investment and (iii) The marginal productivity of capital, (iv) Hedging, facilate the trading, and pooling of risk, (v) Allocate resources ${ }^{[33,44]}$.

In an open economy, technology and knowledge may also be transferred through trade, especially through exports and imports and thus promote economic growth. However, growth also has effects on trade $^{[25]}$ but, at the same time, openness improves the allocative efficiency of the economy. The relationship between openness and economic growth in developing countries has been fully analyzed by a large number of empirical papers. Primary attention has been given to the advantages of an outward-oriented strategy and to the role of exports in economic performance. The role of trade policy and in particular, outward versus inward-oriented trade strategies, has been the focus of considerable academic effort. Openness has been considered one of the main determinants of economic growth in developing countries. The neoclassical model behaves like the Harrod-Domar model implying that openness to trade generates positive growth effects.

Since the time of Smith through Ricardo and Solow, trade has been shown to allow a country to reach a higher level of income since it permits a better allocation of resources. The growth effects of trade openness are made more explicit by the use of the new growth theory led by Romer ${ }^{[49]}$ and Lucas ${ }^{[39]}$. Within such framework, Grossman and Helpman ${ }^{[19]}$ establish that openness enhances economic growth through the following channels. Trade enlarges the available variety of intermediate goods and capital equipment, which can expand the productivity of the country's other resources. Trade permits developing countries the access to improved technology in developed countries, in the form of embodied capital goods. Trade allows intensification of capacity utilization that increases products produced and consumed. Openness offers a larger market for domestic producers, allowing them, on one hand, to operate at minimum required scale and on the other hand, to reap benefits from increasing returns to scale ${ }^{[21]}$.

The Granger-causality between openness and financial development on economic growth are also investigated. The Augmented Dickey-Fuller unit root test and Johansen-Juselius cointegration method are used to estimate the empirical model to investigate the long-run impact of openness and financial development on economic growth. This issue is getting less attention in the literature of the impact of openness or financial development on economic growth.
To this end study aims at investigating causal relationships between trade openness, financial development and economic growth for Turkey over the period 1989M1-2007M11. This study re-examines the literature on trade openness, financial development and growth and reinterprets the findings of the new studies based on monthly data.

Financial development and trade openness: overview of the empirical literature on the causality issue: In the literature, there has been voluminous work, which shows how financial development contributes to economic growth. The empirical work however, on the issue of causality between financial development and economic growth, to this day remains sparse $^{[10,44]}$.

Levine and Renelt ${ }^{[36]}$, they conducted sensitivity analysis in order to identify whether estimates for financial indicators were still robust after including further variables in the information set. They provided a wide variety of financial and economic indicators to represent efficiency of investment and volume of investment channels. They estimated a basic equation for each of the financial and economic indicators in a sample of 77 developing countries over the period 1960-1989. They found that, on average, each of the financial indicators was highly significant and positively correlated with GDP growth per capita. In particular they found that countries, which have been categorized as fast growers, showed higher growth in their financial indicators. Goldsmith ${ }^{[16]}$ was the first to document a positive correlation between growth and indicators of financial development. Simply put by Goldsmith, the financial superstructure of an economy "accelerates economic growth and improves economic performance to the extent that facilitates the transfers of funds to the best users, i.e., to the place in the economic system where the funds will yield the highest social return".

McKinnon $^{[42]}$ and Shaw ${ }^{[53]}$ stimulated the bundle of research that investigates how financial development can stimulate growth. McKinnon and Shaw postulated that government intervention in the financial system of a country, which they termed "financial repression", inhibits growth by depressing real interest rates. Interest rate ceilings, high reserve ratios and directed credit programs were viewed as sources of financial repression; the main symptoms were low savings, credit rationing and low investment. Following Jung ${ }^{[29]}$, employed annual data and more standard measures of output and financial development. He used two proxies for financial development. The analysis was done in a 


\section{J. Social Sci., 5(1): 33-42, 2009}

levels vector autoregressive (VAR) framework. He tested 56 countries of which 19 were industrial countries. There were no clear results for the developed countries. The currency ratio proxy suggested that economic growth leads to financial development, while the monetization proxy suggested that financial development leads to economic growth.

King and Levine ${ }^{[32]}$, find a strong and robust correlation between financial indicators and economic performance, study of 80 countries over the 1960-1989period. Murende and Eng ${ }^{[43]}$ initiated the studies using co-integration and unit root techniques within a bivariate VAR (BVAR) framework in testing the issue. The country sample used was Singapore with quarterly data spanning from 1979-1990. The evidence presented largely supports a unidirectional causality from financial development to economic growth. The authors consider that such a result is on line with the deliberate financial restructuring policy, implemented by the Government in the eighties. The reforms achieved in Singapore aimed at developing bank intermediation and enhancing monetization and financial services in order to increase real growth.

In opposite to Murende and Eng ${ }^{[43]}$, Demetriades and Hussein ${ }^{[10]}$ found a considerable evidence of bedirectionality between financial development and growth for a set of 16 developing countries during different periods. They concluded that causality patterns have tendency to vary with countries and more specifically with the outcomes of financial reforms implemented.

Gregorio and Guidotti ${ }^{[18]}$ studied 100 countries during the 1960-1989 periods. They concluded that financial development leads to an improved growth performance. Roubini and Sala-i- Martin ${ }^{[50]}$ found that growth was negatively correlated with the bank reserve ratio as a proxy for financial repression that was not likely to be affected by economic growth.

Arestis and Demetriades ${ }^{[2]}$ took a fresh look at the empirical evidence on the relationship between financial development and economic growth in Germany and the United States. They included in their proxy for financial development stock market data. Using quarterly data and they employed four proxies.

Hansson and Jonung ${ }^{[23]}$ examine the long-run relationship between finance and economic growth in Sweden from the 1830s until the 1990s uses recently developed econometric techniques for tests of cointegration. The empirical work suggests that there has been a pattern of interaction among the variables examined. The estimated contribution of the financial system to economic growth is shown to depend crucially on the time period studied and the variables included in the analysis.

Kul and $\mathrm{Khan}^{[34]}$ carried out time series tests of the finance and growth relationship in a Multivariate Vector Auto-Regression (MVAR) framework with cointegration tests. They found that the long run financial intermediation and growth ties are featured by a bidirectional causality for all the countries of the sample. Such outcomes were accounted for by the usage of new approaches and methods in testing this causality and the higher dimensional system.

Kar and Pentecost ${ }^{[31]}$ empirical results show that the direction of causality between financial development and economic growth is sensitive to the choice of measurement for financial development in Turkey. There can therefore be no "wholesale" acceptance of the view that "finance leads growth" just as there can be no wholesale acceptance of the view that "finance follows growth" in Turkey. The results do however; imply that the strength of the causality between financial development and economic growth are much weaker than that between economic growth and financial development. Indeed it would not be inconsistent with the results obtained to argue that for all intents and purposes in Turkey economic growth lead financial development.

Rousseau and Sylla ${ }^{[51]}$ find a robust correlation between financial factors and economic growth that is consistent with a leading role for finance in a broad cross section of seventeen economies over the 18501997 terms. The result of this study is that the economic growth and increases globalization of the Atlantic economies might indeed have been finance led.

Shan, Morris and Sun $^{[52]}$ use a Granger causality procedure to investigate the relationship between financial development and economic growth for nine OECD countries and China by estimating a vector autoregression (VAR) model. The results of their study show that five out of ten countries have a bilateral Granger causality; three of them have reverse causality with economic growth leading to financial development while two countries do not have a causal effect at all.

In the literature, there has been seriously work, which shows causality between trade openness and economic growth. As for the empirical investigation, disagreement concerning the analysis of the effects of trade on growth usually turns around the three following issues: the construction of a single appropriate trade openness index, the use of crosssection analysis and the direction of causality. Measures vastly used, among other proxies, are ratio of trade (sum of imports and exports) to GDP, the importance of 
tariffs and the coverage of non-tariff barriers. Rodrik ${ }^{[48]}$ argues that in most studies of openness and growth, indicators used inappropriately reflect the trade regime.

Jung and Marshall ${ }^{[30]}$ were among the first to question simple conclusions from OLS regressions. For the period of from 1950-1981, they find the direction of causality between exports and growth to be inconclusive, with results ranging from exports that cause growth (Indonesia) and growth causes exports (Thailand) to exports that yield less growth (Korea) and no causal relationship at all (Philippines and Taiwan).

Rodrik $^{[48]}$ studies four countries (Korea, Taiwan, Chile and Turkey) and presents very briefly Granger causality tests between the share of investment in GDP and the share of exports plus imports in GDP. He finds, suggesting possibly country specific aspects, no unambiguous links. In Korea investment has Grangercaused trade while in Taiwan investment has Grangercaused trade and trade has Granger-caused investment. No causality could be detected for either direction in Chile and Turkey.

Van Den Berg ${ }^{[58]}$ addresses the causality controversy in six Latin American countries by comparing results from single equation and simultaneous equation models. He argues that, first, both imports and exports have positive and distinct effects on economic growth; second, there exists a simultaneity between trade and growth; and finally, impacts of openness on growth are higher and more significant through a simultaneous over a single equation model.

Harrison $^{[24]}$ studies the effects of trade openness on growth using panel data and compares predictions of several measures of trade openness. According to Granger causality tests results; openness and growth cause each other in both directions.

Hatemi and Irandoust ${ }^{[26]}$ study the direction of causality between export and productivity in five OECD countries. First, the Johansen method suggests the existence of one cointegrating vector between export and productivity. Then, the Granger causality test augmented with the error-correction term is carried out for each country. Although results are rather disparate, causality generally runs from export to productivity.

Utkulu and Özdemir ${ }^{[57]}$ examine the long-run relationship between financial and economic growth in Turkey. They found that a relationship between openness and growth is theoretically plausible, while a causal link from declining trade distortions to growth is also consistent with the hypothesised role of trade policy in the 'new' growth theory. Trade policy affects growth in both the short and long run.

Brief historical background of the Turkish economy: In 1980, a package of economic stability measures known as "January 24 Decisions" were adopted to restore the worsened problems emerged in the late 1970's. In addition to restore the Turkish economy, "January 24 Decisions" also introduced radical changes in economic modeling and preferences. With those decisions Turkey switched its economic policy from "import substituting industrialization" to "export-led growth strategy" which brought about the introduction of liberalization in financial markets and more emphasis on foreign trade ${ }^{[12]}$.

In 1986, Turkish Government launched for the first time to borrow from the international markets by issuing Treasury Bills and Government Bonds.

In 1989, capital account liberalization was introduced and Turkish Lira became convertible, so foreigners began to purchase stocks (government bonds, equities, bills) from Turkey and foreign exchange deposits were allowed in Turkish banks.

In 1990, the adopted economic approach, amendments in legal procedures, newly established institutions, free flow of capital movements, improved level of communication technology, the policy of funding the public sector have been concretely effective on the economy as of the beginning of 1990. Furthermore, the effects of Customs Union with the European Union (EU) were added to those mentioned in $1995^{[1]}$.

In 1994, huge requirements for public sector borrowing in 1993 and early 1994, combined with major policy errors in financing the deficit, led to Turkey's currency crisis in 1994. As a result of Turkey's currency crisis in 1994, output fell 6 percent, inflation rose to three-digit levels, the Central Bank lost half of its reserves and the exchange rate (against the US Dollar) depreciated by more than half in the first three months of the year.

In 1995, the rapid growth cycle in the Turkish economy, which began in 1995, continued until April 1998. The main factors that terminated this trend are as follows:

- Measures were taken in the framework of targeting $50 \%$ inflation

- The effect of capital outflow on the real sector, which occurred due mainly to the belief that Turkey might be influenced by the Russian Crisis starting in August 
- The contraction of world demand, which started with the capital outflow in almost all of the developing countries following the 1997 Southeast Asian Crisis

- In the real sector, excess capacity was established due to the heavy investments after the Customs Union agreement with EU. This excess capacity led to financial problems stemming from the contraction of domestic and foreign demand

In 1999, Turkish economy experienced a serious contraction after the successive years of high growth in the post-1994 crisis period. The slowdown in economic activities due to the measures takes to bring down the inflation in 1998 became a severe contraction as the Russian crisis had spilled over the global markets. In addition more difficulties became worse with the devastating earthquakes in August and November in 1999. Beginning in 1999, the International Monetary Fund (IMF) has exerted strong pressure to reform the economic system. After the April 1999 elections, the new government launched an economic stabilization program aiming to achieve a stable and sound economic growth by reducing the budget deficit and the inflation rate. As set forth in the "letter of intent" submitted to the IMF in December 1999, the program was based on three pillars which are "up-front fiscal adjustment", "structural reforms" and a "firm exchange rate commitment supported by consistent income policy". Incorporated in strict fiscal and monetary policies, this program has succeeded to decrease the inflation rate considerably.

In 2000 and 2001, economic measures take by the government under the supervision of IMF for the Turkish economy could not prevent financial crises of November 2000 and February 2001 which caused a serious contraction in 2001. As a result of the collapse of the fixed exchange regime and 50\% depreciation of the Turkish Lira in February 2001, Turkey's ambitious IMF backed stabilization program has been amended. The revised IMF program was intended to ensure timely debt repayments, prevent further devaluation, control the rise of inflation and support the solvency of the banking system. The strong structural reforms, prudent fiscal and monetary policies under a floating exchange rate regime and an enhanced social dialogue were the main pillars of the revised program launched in March 2001.

In 2001, "The Banking Sector Restructuring Program" was initiated with the aim of modifying the banking sector into a sound and competitive structure in consistent with the sustainable growth. The main components of the program can be summarized as follows:

- Financial and operational restructuring of the state banks to towards the goal of privatization

- Amelioration of the SDIF banks by using the methods of merger, sale or liquidation

- Strengthening the financial structure of the private banks

- Ensuring efficient supervision, auditing and competition conditions by completing legal and institutional framework

In 2002, a considerable economic recovery began to be observed, along with the structural reforms and macroeconomic policies, which were implemented in the aftermath of the financial crisis and later converted into a new three-year economic program.

Liberalized import regime, new foreign investment and export promotion policies have enabled Turkey to take its place in the global economy. In this context, steady economic growth has been accompanied by a significant change in the composition of the GNP, the share of industry and services marking an important increase.

\section{MATERIALS AND METHODS}

Data: In recent years there have been different empirical works which have shown that causation runs from financial development to economic growth, that there is a bidirectional effect, or that economic growth leads to financial development, some papers have even made a case for independent causation between growth and finance. Several indicators of financial development have been proposed in the literature. Different indicators will proxy different aspects of the relationship between the financial system and economic performance. Verifying the relationship between financial development and growth has at least two problems. First, it is necessary to assume a measure for financial development. And, secondly, many econometrics articles about this lemma do not use a theoretical model. In relation to the first problem, it will be used two variables as a proxy to financial development:

- Liquid liabilities divided by GDP (usually M2 divided by GDP)

- Liquid liabilities (M2). The proxy to growth indicator is GDP 
In the literature, the most commonly used measure of financial development is a ratio of some monetary aggregates, usually M2, some times M2Y, M3 or M3M1, to the $\operatorname{GDP}^{[2,4,7,8,18,20,29,31,33,37,38,43,50,54]}$.

In the literature, the most commonly used measure of trade or economic openness is the ratio of sum of imports and exports to GDP ${ }^{[6,46,51,54]}$.

Following beyond literature, in this study, the proxy of trade openness calculated as the ratio of the sum of the exports and imports to GDP and the proxy of financial development calculated as the ratio of M2Y to GDP for Turkey over the period 1989M1 to 2007M11. Monthly GDP data is taken from Tasdemir ${ }^{[56]}$ and other data used in this study are taken from International financial Statistics and transformed to logarithmic from achieve stationary in variance and seasonal adjusted.

\section{RESULTS}

A necessary condition for testing for a long-run relationship among variables is that these variables are $\mathrm{I}(1)$, i.e., stationary in first differences. We, therefore, use the classical unit root test, namely, the Augmented Dickey-Fuller (ADF) test. ADF test is based on the null hypothesis that a unit root exists in the time series. Once it is established that series are I(1), we can proceed to test for a long-run relationship between the series. If such a relationship exists, the series are cointegrated. We tested cointegration using the two cointegration techniques devised by Johansen and Juselius (JJ) ${ }^{[27]}$.

The traditional Granger causality test uses the simple F-test statistics. Several studies such as Marin $^{[40]}$, Pomponio ${ }^{[45]}$, McCarville and Nnadozie ${ }^{[41]}$, Darat $^{[9]}$ have used the raditional (F-test) to test for causality. The use of a simple traditional Granger causality has been identified by several studies ${ }^{[14,52]}$ as not sufficient if variables are 1(1) and cointegrated. If time series included in the analysis are 1(1) and cointegrated, the traditional Granger causality test should not be used and proper statistical inference can be obtained by analysing the causality relationship on the basis of the error correction model (ECM). Many economic time-series are 1(1) and when they are cointegrated, the simple F-test statistic does not have a Standard distribution ${ }^{[28]}$.

We first perform unit root tests in levels and first differences in order to determine univariate properties of the series used in this study. The results are shown in Table 1. Test results indicate that the hypothesis of a unit root in level series cannot be rejected at the 5\% level of confidence, suggesting that the variables are not level stationary. Table 1 also shows that the ADF statistics for the four variables imply first-difference stationary. After establishing thestationarity of the data, Johansen multivariate cointegration tests are used to explore any possible long run relationship among the variables. This involves testing the number of cointegrating vectors.

Before undertaking cointegration tests, let us first specify the relevant order of lags of the vector autoregression (VAR) model. Lag order was determined using the Schwarz Bayesian Criterion (SBC) and Akaike's Information Criterion (AIC). Lag in VAR model is 6 for the model. The results obtained from the Johansen-Juselius cointegration method are shown in Table 2.

The null hypothesis of no cointegration, i.e., $r=0$ can be rejected either using the maximum eigenvalue or the trace statistic. They are both greater than their critical value. The null of $r=1$ can not be rejected in favor of $r=2$. Thus, there is only one cointegrating vector in the model. Therefore, our monthly data from 1989M1-2007M11 appear to support the proposition that in Turkey there exist a stable long-run relationship among the variables. Long-run cointegrating relationship is shown in Table 3 .

Table 1: ADF unit root test results

\begin{tabular}{|c|c|c|c|c|}
\hline \multirow[b]{2}{*}{ Series } & \multicolumn{2}{|l|}{ Level } & \multicolumn{2}{|c|}{ First difference } \\
\hline & $\tau_{\tau}$ & $\tau_{\mu}$ & $\tau_{\tau}$ & $\tau_{\mu}$ \\
\hline LGDP & $-0.637(1)$ & $-2.428(1)$ & $-24.085(0)^{*}$ & $-24.032(0)^{*}$ \\
\hline $\mathrm{OP}$ & $-0.786(13)$ & $-1.628(13)$ & $-3.464(12)^{*}$ & $-3.668(0)^{* *}$ \\
\hline FD & $-0.429(1)$ & $-1.728(1)$ & $-19.108(0)^{*}$ & $-19.135(0)^{*}$ \\
\hline
\end{tabular}

Note: The $t$ statistics refer to the ADF tests. The subscripts $\mu$ and $\tau$ indicates the models that allow for an intercept and intercept\&trend, respectively. Asterisk (*and**), shows significance at 1 and 5\% level. Figures in parentheses indicate the lag length (SBC)

Table 2: Johansen-Juselius maximum likelihood cointegration tests

\begin{tabular}{|c|c|c|c|c|c|c|c|}
\hline \multicolumn{4}{|c|}{ Trace test } & \multicolumn{4}{|c|}{ Maximum eigenvalue test } \\
\hline Null & Alternative & statistic & $95 \%$ critical value & Null & Alternative & Statistic & $95 \%$ critical value \\
\hline $\mathrm{r}=0$ & $\mathrm{r} \geq 1$ & $34.750 *$ & 29.797 & $r=0$ & $r=1$ & $25.922 *$ & 21.131 \\
\hline $\mathrm{r} \leq 1$ & $\mathrm{r} \geq 2$ & 8.828 & 15.494 & $r \leq 1$ & $r=2$ & 8.357 & 14.264 \\
\hline $\mathrm{r} \leq 2$ & $r \geq 3$ & 0.471 & 3.841 & $r \leq 2$ & $r=3$ & 0.471 & 3.841 \\
\hline
\end{tabular}

Note: (1): We have employed SBC and AIC criterion in the determination of lag length in the VAR model; (2): Asterisks (*) denotes statistical significance at $5 \%$ stands for the number of cointegrating vectors 


\section{J. Social Sci., 5(1): 33-42, 2009}

Table 3: Estimates of long-run cointegrating relationship

\begin{tabular}{lll}
\hline Dependent variable & LOP & LFD \\
\hline LGDP & -4.820200 & 0.513121 \\
& $(0.63107)$ & $(0.65393)$
\end{tabular}

Note: Figures in parentheses indicate the standard error of coefficients

Table 4: Granger causality test from ECM's: Multivariate case Wald Statistics (Prob)

\begin{tabular}{lllll} 
Dependent & & & & \\
Variable & $\Delta$ LGDP & $\Delta$ LOP & $\Delta$ LFD & EC $_{\text {t-1 }}[$ t-stat] \\
\hline$\Delta$ LGDP & - & $12.082(0.002)$ & $8.921(0.016)$ & $0.67[3.55]$ \\
$\Delta$ LOP & $4.885(0.086)$ & - & $6.047 .(0.048)$ & $-0.13[-7.89]$ \\
$\Delta$ LFD & $22.457(0.000)$ & $7.452 .(0.024)$ & - & $-0.15[-6.99]$ \\
Causality & & & &
\end{tabular}

direction

(a): All estimates are achieved using level of integrated variables; (b): The wald-statistics are significant at the 5\% level; (c): The order of the lag is determined using the Schwarz Criterion (SC) on the unrestricted bVAR

Since there is cointegration between the variables, the direction of causality is tested by using the vector error correction model with existing of a cointegrating vector. Also examine the direction of causal relationship between financial development, trade openness and growth by employing bivariate granger causality tests using lag length under the null hypothesis of noncausality. The order of the lag is determined using the Schwarz Criterion (SC) on the unrestricted BVAR. The results of the Granger causality test are shown in Table 4 . The results show that there exists bi-directional causality among economic growth, financial development and trade openness. The coefficient of the EC term, using a traditional t-test, is found to be statistically significant. EC term show that growth rate is corrected by according to changing in financial development and trade openness.

\section{DISCUSSION}

Although there exists wide spread evidence that indicates both trade openness and financial development have positive effects on growth in the empirical literature, the findings in Table 3 show that financial development has a negative effect on economic growth. This result may be thought in contradiction with general evidence in the empirical literature. Possible explanation for this result might be related to the fact that: the crises dummy variables (dummy is equal to 1 for 1994M4 and 2001M2, zero for others) have used for exog variable in the VAR system. As far as is known, the financial markets and structures of developing countries are more vulnerable to crises.

The estimation results of long-run cointegrating relationship show the presence of positive relationship between trade openness and growth and negative relationship between financial development and growth. It is possible say to the negative effect of financial development on growth is bigger than the positive effect of trade openness. This finding supports the theoretical approach in which trade openness can be positively affecting on developing countries economic performances. Thus, applications of financial liberalization policies increase risk for foreign investments and to make macroeconomic stability difficult in view of the shocks.

The findings obtained from the causality tests show that there are bicausal relationship between growth and financial development and between growth and trade openness at $5 \%$ significance level. Furthermore financial development and trade openness cause growth.

Taken together, the results show trade openness and financial development to have a significant impact on economic growth and the findings are compatible with major portion of the literature.

\section{CONCLUSION}

The Granger causality test indicates bicausality between financial development and economic growth and trade openness and economic growth, to the Turkish economy in the period from 1989M1-2007M11

Although the Turkish economy downturn was due to the major crises (in 1994 and 2001) significant improvements have been appearing in the Turkish economy after crises and earthquakes due to the applied economic policies. These policies have positive effect on financial system and trade. It means that economic policies that affect financial development and trade openness will have positive impact on GDP and viceversa is also true.

Turkish financial and banking regulations have been overhauled since 1990s, partly in response to the crisis. Improvements of financial system have a positive effect on GDP. The causality test results support this inference. There are bicausality between financial development and economic growth. Bidirectional causality could mean that Turkey's economic growth plays a key role by determining both the demand and supply sides of liquid liabilities. Additionally, bidirectional causality between liquid liabilities and economic growth may suggest that the growth in liquid 
liabilities in Turkey after 1989 played both a leading and accommodative role in economic growth.

The other important point is that the liberalization of trade with the European Union as a result of the customs union agreement with EU in 1995 (completed in 1996). EU countries are most important patterns of Turkey. As a result of elimination of trade barriers, Turkish foreign trade volume has increase. Therefore, the impact of Turkey's trade liberalization and increased openness on GDP is positive. At the same time, increased GDP has also prompted trade. In other words, there are bicausality between trade openness and economic growth.

\section{REFERENCES}

1. Alici, A.A. and M.S. Ucal, 2003. Foreign direct investment, exports and output growth of turkey: causality analysis. Proceeding of the 5th Annual Conference on European Trade Study Group, Sept. 11-13, Universidad Carlos III de Madrid, Madrid, pp: 1-19.

http://www.etsg.org/ETSG2003/papers/alici.pdf

2 Arestis, P. and P. Demetriades, 1997. Financial development and economic growth: Assessing the evidence. Econ. J., 107: 783-99. http://ideas.repec.org/a/ecj/econjl/v107y1997i442p 783-99.html

3. Berthelemy, J.C. and A. Varoudakis, 1995. Thresholds in financial development and economic growth. Manchester School Econ. Soc. Stud., 63: 70-84.

http://ideas.repec.org/a/bla/manch2/v63y1995i0p70 -84.html

4. Boulila, G. and M. Trabelsi, 2004. The causality issue in the finance and growth nexus: Empirical evidence from middle east and North African countries. Rev. Middle East Econ. Finance, 2: 123. http://ideas.repec.org/a/bep/rmeecf/2200423.html

5. Cameron, R., 1967. Banking in the Early Stages of Industrialization. 1st Edn., Oxford University Press, New York, USA., pp: 349.

6. Chang, T., 2002. Financial dvelopment and economic growth in mainland China: A note on testing demand-following or supply-leading hypothesis. Applied Econ. Lett., 9: 869-873. DOI: 10.1080/13504850210158962

7. Coricelli, F., 1996. Finance and growth in economies in transition. Eur. Econ. Rev., 40: 645-653. http://ideas.repec.org/a/eee/eecrev/v40y1996i35p645-653.html
8. Darrat, A., 1999. Are financial Deepending and economic growth causally related? Another look at the evidence. Int. Econ. J., 13: 19-35. http://ideas.repec.org/a/taf/intecj/v13y1999i3p19-35.html

9. Darat, A.E., 1996. Trade and development: The Asian experience. Cato J., 6: 695-699. http://www.cato.org/pubs/journal/cj6n2/cj6n2-16.pdf

10. Demetriades, P. and K. Hussein, 1996. Does financial development cause economic growth? Time series evidence from 16 countries. J. Develop. $\quad$ Econ., 51: 387-411. http://ideas.repec.org/p/kee/keeldp/95-13.html

11. Demetriades, P.O. and K.B. Luintel, 1996. Financial development, economic growth and banking sector controls: Evidence from India. Econ. J., 106: 359-374. http://ideas.repec.org/a/ecj/econjl/v106y1996i435p 359-74.html

12. Doganlar, M., 1998. Testing for the structural break in the Turkish foreign trade. J. Cukurova FEAS., 8: 333-340.

13. Edison, H.J., R. Levine, L. Ricci and T. Sløk, 2002. International financial integration and economic growth. J. Int. Money Finance, 21: 749-776. http://www.nber.org/papers/w9164

14. Engle, R.F. and C.W.J. Granger, 1987. Cointegration and error correction: Representation, estimation and testing. Econometrica, 55: 251-276. http://ideas.repec.org/a/ecm/emetrp/v55y1987i2p2 51-76.html

15. Fry, M.J., 1997. In favour of financial liberalization. Econ. J., 107: 754-70. http://ideas.repec.org/a/ecj/econjl/v107y1997i442p 754-70.html

16. Goldsmith, R., 1969. Financial Structure and Development. 1st Edn., Yale University Press, New Haven, ISBN: 10: 0300011709, pp: 561.

17. Graff, M., 2003. Financial development and economic growth in corporatist and liberal market economies. Emerg. Merk. Financ. Trade, 39: 47-69. http://papers.ssrn.com/sol3/papers.cfm?abstract_id $=286052$

18. Gregorio, J.D. and P.E. Guidotti, 1995. Financial development and economic growth. World Develop., 23: 433-448. http://ideas.repec.org/p/fip/fedpwp/99-11.html

19. Grossman, G.M. and E. Helpman, 1991. Growth and Welfare in a Small Open Economy. In: International Trade and Trade Policy, Helpman, E. and A. Razin (Eds.). MIT Press, Cambridge MA., pp: 141-163. 
20. Gupta, K.L., 1984. Finance and Economic Growth in Developing Countries. 1st Edn., Croom Helm., ISBN: 0709938039, pp: 241.

21. Hamori, S. and I.F. Razafımahefa, 2003. Trade and growth relationship: Some evidence from comoros, madagascar, mauritius and Seychelles. Asian Afr. Area Stud., 3: 174-186. http://www.asafas.kyotou.ac.jp/publication/pdf/no_03/p174_185.pdf

22. Hansen, P.R. and S. Johansen, 1998. Workbook on Cointegration. 1st Edn, Oxford University Press, ISBN: 10: 0198776071, pp: 176.

23. Hansson, P. and L. Jonung, 1997. Finance and economic growth the case of Sweden 1834-1991. Res. Econ., 51: 275-301. http://swopec.hhs.se/hastef/papers/hastef0176.pdf.zip

24. Harrison, A., 1996. Openness and growth: A timeseries, cross-country analysis for developing countries. J. Develop. Econ., 48: 419-447. http://econpapers.repec.org/paper/wbkwbrwps/809.htm

25. Hsiao, F.S.T. and M.C.W. Hsiao, 2006. FDI, exports and GDP in East and Southeast Asia- panel data versus time-series causality analyses. J. Asian Econ., 17: 1082-1106. DOI: 10.1016/j.asieco.2006.09.011

26. Hatemi, A.J. and M. Irandoust, 2001. Productivity performance and export performance: A timeseries perspective. Eastern Econ. J., 27: 149-164. http://ideas.repec.org/a/eej/eeconj/v27y2001i2p149 $-164 . h t m l$

27. Johansen, S. and K. Juselius, 1990. Maximum likelihood estimation and inferences on cointegration with application to the demand for money. Oxford Bull. Econ. Stat., 52: 169-210. http://ideas.repec.org/a/bla/obuest/v52y1990i2p169 $-210 . h \mathrm{tml}$

28. Jordaan, A.C. and J.H. Eita, 2007. Export and economic growth in namibia: A granger causality analysis. South Afr. J. Econ., 75: 540-547.

29. Jung, W.S., 1986. Financial development and economic growth: International evidence. Econ. Develop. Cultur. Change, 32: 333-346. http://ideas.repec.org/a/ucp/ecdecc/v34y1986i2p33 3-46.html

30. Jung, W.S. and P.J. Marshall, 1985. Exports, growth and causality in developing countries. J. Develop. $\quad$ Econ., 18: 1-12. http://ideas.repec.org/a/eee/deveco/v18y1985i1p112.html

31. Kar, M. and E.J. Pentecost, 2000. Financial development and economic growth in Turkey: Further evidence on the causality issue. Economic Research Paper No. 00/27. http://www.econturk.org/muhsinkar.pdf
32. King, R.G. and R. Levine, 1993a. Finance and growth: Schumpeter might be right. Q. J. Econ., 108: 717-737. http://ideas.repec.org/a/tpr/qjecon/v108y1993i3p71 7-37.html

33. King, R.G. and R. Levine, 1993b. Finance, entrepreneurship and growth: Theory and evidence. J. Monet. Econ., 32: 513-542. http://ideas.repec.org/a/eee/moneco/v32y1993i3p5 13-542.html

34. Kul, B.L. and M. Khan, 1999. A quantitative reassessment of the finance-growth nexus: evidence from a multivariate VAR. J. Develop. Econ., 60: 381-405.

http://ideas.repec.org/a/eee/deveco/v60y1999i2p38 1-405.html

35. Levine, R., 1997. Financial development and economic growth: Views and agenda. J. Econ. Literat., 35: 688-726. http://web.nps.navy.mil/ relooney/levine.pdf

36. Levine, R. and D. Renelt, 1992. A sensitivity analysis of cross-country growth regressions. Am. Econ. Rev., 82: 942-63. http://ideas.repec.org/a/aea/aecrev/v82y1992i4p94 2-63.html

37. Liu, X., H. Song and P. Romilly, 1997. An empirical investigation of the causal relationship between openness and economic growth in China. Applied Econ., 29: 1679-86. http://ideas.repec.org/a/taf/applec/v29y1997i12p16 79-1686.html

38. Lyons, S.E. and V. Murinde, 1994. Cointegration and granger-causality testing of hypotheses on supply-leading and demand-following finance. Econ. Notes, 23: 308-316. http://direct.bl.uk/bld/PlaceOrder.do?UIN=024192 003\&ETOC $=\mathrm{EN} \&$ from $=$ searchengine

39. Lucas, R.E., 1988. On the mechanics of economic development. J. Monet. Econ., 22:3-42. http://ideas.repec.org/a/eee/moneco/v22y1988i1p342.html

40. Marin, D., 1992. Is the export-led growth hypothesis valid for industrialised countries? Rev. Econ. Stat., 74: 678-688. http://www.inomics.com/cgi/repec?handle=RePEc: tpr:restat:v:74:y:1992:i:4:p:678-88

41. McCarville, M. and E. Nnadozie, 1995. Causality test of export-led growth: The case of Mexico. Atlant. Econ. J., 23: 140-145. DOI: 10.1007/BF02300439

42. McKinnon, R.I., 1973. Money and Capital in Economic Development. 1st Edn., Brookings Institution, Washington DC., USA., ISBN: 10: 0815756135, pp: 177. 
43. Murinde, V. and F. Eng, 1994. Financial development and economic growth in Singapore: Demand-following or supply-leading? Applied Financ. $\quad$ Econ., 4: 391-404. http://econpapers.repec.org/article/tafapfiec/v_3a4_ 3ay_3a1994_3ai_3a6_3ap_3a391-404.htm

44. Pagano, M., 1993. Financial markets and growth an overview European. Econ. Rev., 37: 613-622. http://ideas.repec.org/a/eee/eecrev/v37y1993i23p613-622.html

45. Pomponio, X. Z., 1996. A causality analysis of growth and export performance. Atlant. Econ. J., 24: 168-176. DOI: 10.1007/BF02299007

46. Quispe-Agnoli, M. and E. McQuerry, 2001. Measuring financial liberalization in Latin America: An index of banking activity. Proceeding of the Conference on Federal Reserve Bank of Atlanta, Domestic Finance and Global Capital in Latin America, Nov. 1-2, USA., pp: 1-39. http://www.frbatlanta.org/econ_rd/larg/events/conf 2001/quispe-mcquerry_paper.pdf

47. Rodrik, D., 1995. Trade Policy and Industrial Policy Reform. In: Handbook of Development Economics, Jere Behrman and T.N. Srinivasan (Eds.). Elsevier Science, USA., pp: 2925-2982.

48. Rodrik, D., 1997. Trade strategy, investment and exports: Another look at East Asia. Pacif. Econ. Rev., 2: 1-24. DOI: 10.1111/1468-0106.t01-100020

49. Romer, P.M., 1986. Increasing returns and longrun growth. J. Polit. Econ., 94: 1002-1037. http://ideas.repec.org/a/ucp/jpolec/v94y1986i5p100 2-37.html

50. Roubini, N. and X. Sala-I-Martin, 1995. A growth model of inflation, tax evasion and financial repression. J. Monet. Econ., 35: 275-301. DOI: 10.1016/0304-3932(95)01192-Q
51. Rousseau, P.L. and R. Sylla, 2001. Financial systems, economic growth and globalization. http://www.nber.org/papers/w8323.pdf?new_wind $\mathrm{ow}=1$

52. Shan, J. and A. Morris, 2002. Does financial development lead economic growth? Int. Rev. Applied Econ., 16: 153-168. http://ideas.repec.org/a/taf/irapec/v16y2002i2p153168.html

53. Shaw, E.S., 1973. Financial Development in Economic Development. 1st Edn., Oxford University Press, New York, USA., pp: xii-260.

54. Siddiki, J.U., 2002. Trade and financial liberalisation and endogenous growth in Bangladesh. Int. Econ. J., 16: 23-37.

55. Singh, A., 1997. Financial liberalization, stockmarkets and economic development. Econ. J., 107: 771-82. http://www.jstor.org/pss/2957801

56. Tasdemir, M., 2008. Estimating monthly GDP for Turkey by state-space approach. Int. Res. J. Finance Econ., 17: 144-151. http://www.eurojournals.com/Pages\%20from\%20ir jfe17murat.pdf

57. Utkulu, U. and D. Özdemir, 2004. Does trade liberalization cause a long run economic growth in turkey. Econ. Plann., 37: 245-266. DOI: 10.1007/s10644-005-8080-8

58. Van Den Berg, H., 1996. Does simultaneity exaggerate empirical tests of trade-growth relationship. Applied Econ. Lett., 3: 225-231. http://ideas.repec.org/a/taf/apeclt/v3y1996i4p22531.html 